\title{
Lexical Constraints on the Formation of -er Nominals Derived from Intransitive Verbs
}

\author{
Li-li Wu $\mathbf{u}^{1,2}$ \\ ${ }^{1}$ School of Foreign Languages, Huaiyin Normal University, China \\ ${ }^{2}$ Graduate School of International Cultural Studies, Tohoku University, Japan
}

Copyright $\odot 2019$ by authors, all rights reserved. Authors agree that this article remains permanently open access under the terms of the Creative Commons Attribution License 4.0 International License

\begin{abstract}
The English suffix -er has long been considered as a morpho-syntactic diagnostic for split intransitivity since -er nominals are derived only from verbs that have external arguments. Therefore, the formation of an -er nominal derived from an intransitive verb should be based on an unergative verb (a verb that has an external argument) instead of an unaccusative one (a verb that has an internal argument). As split intransitivity is syntactically represented but semantically determined, the formation of $-e r$ nominals is actually semantically predictable. Two approaches in the literature, the projectionist and gradient approach, give a detailed explanation for the semantic constraints on determining a verb' argument as either external or internal. Compared with the projectionist approach, the gradient approach seems to offer a better account to predict some verbs are more consistent in forming an -er nominal while others exhibit variation.
\end{abstract}

Keywords Lexical Constraints, -er Nominal, Split Intransitivity, the Projectionist Approach, the Gradient Approach

\section{Introduction}

The split of intransitive verbs into unaccusatives and unergatives is called split intransitivity. The single argument of an unaccusative verb is internal because it is base generated in the complement position. The single argument of an unergative verb, on the contrary, is external because it is base generated in the specifier position of the verb phrase $[1,2]$. Evidence for the distinction is both syntactic and semantic. In English, there are many syntactic diagnostics that are claimed to be sensitive to the unaccusative-unergative distinction. Among them, the suffix -er is considered as a diagnostic of split intransitivity since -er nominals are derived only from verbs that have external arguments $[3,4,5,6]$. Given the hypothesis that all -er nominals refer to the external argument of the base verb, it is hypothesized that the formation of an -er nominal should be based on an unergative verb instead of an unaccusative verb since the single argument of the former is external while the single argument of the latter is internal.

In addition to the syntactic evidence, further evidence for the unaccusative-unergative distinction is semantic. Following Levin and Rapport Hovav [7], split intransitivity is syntactically represented but semantically determined. The class membership of intransitive verbs and the syntactic expression of arguments, to some extent, can be predicted on the basis of lexical semantic properties of the verb. The formation of -er nominals is therefore semantically predictable. According to Perlmutter [1], agentivity has a decisive role to play in determining a verb's status as unergative. The single argument of unergative verbs tends to be an agent, which is external. Researchers also found that lexical aspectual notions such as telicity and stativity are relevant for the unaccusative-unergative distinction. In particular, Van Valin [8] and Dowty [9] stress the importance of both agentivity and telicity in determining the external and internal argument of split intransitivity.

However, the relationship between lexical semantic properties and syntactic expressions of split intransitivity is much more complicated than expected. Empirical data have repeatedly shown that there seems to be an imperfect match between the verbs expected to be selected as either unaccusative or unergative by different diagnostics and the verbs actually selected by those diagnostics. The situation is known as unaccusative mismatches [10].

Take -er nominals as an example. It is widely held that the formation of -er nominals generally obeys the External Argument Generalization, on which the status of -er nominals as the morphosyntactic diagnostic of split intransitivity is established. For example, -er nominal formations with unaccusatives verbs are quite bad (e.g. 
*arriver, *appearer, *laster $)^{1}$. Some researchers, however, argue that some -er nominals with unaccusative verbs are actually possible in some contexts [11]. On the other hand, some other researchers claim that these unaccusative verbs can be reanalyzed as unergative verbs in certain contexts [12]. Questions arise then: which aspects of verb meaning are relevant to determine a verb's argument structure as internal or external? Why do some unaccusative verbs show consistent behavior in the formation of -er nominals while some others exhibit variable behaviors?

Various hypotheses have been proposed to tackle the so-called unaccusative mismatches, and try to identify the syntactically relevant semantic properties of the verb. The projectionist approach and the gradient approach, among all the syntactic, semantic or syntax-semantics interface approaches, are the most promising. This paper aims to examine the lexical constraints on the formation of -er nominals derived from intransitive verbs through a detailed account of the two approaches. These two approaches, which impose different semantic constraints on the formation of -er nominals are illustrated in detail in the following part.

\section{The Projectionist Approach}

The projectionist approach mainly emphasizes the complex mappings between the level of lexical-semantic representation and the level of lexical-syntactic representation. The approach claims that the syntactically relevant semantic properties are first mapped onto the argument structure associated with unaccusativity or unergativity according to some linking principles. Then the lexical-syntactic representation is mapped trivially onto a syntactic structure representation. One of the most influential works of this type is Levin and Rapport Hovav's model [7]. They propose four linking rules which map lexical semantic components of verb meaning underlying the unaccusative and unergative split onto positions at argument structure.

The first linking rule is 'the Immediate Cause Linking Rule, which maps the argument of a verb denoting the immediate cause to the external argument' [7]. This rule captures the generalization that internally caused verbs typically receive an unergative status. Agentivity is subsumed under internal causation, since most unergative verbs are agentive. In English, evidence for agentive verbs to be classified as unergative verbs is provided by the formation of -er nominals. - $E r$ nominals can be derived from those agentive verbs such as worker, player, talker

1 Although Oxford English Dictionary list words like arriver, appearer, laster in the entries, they are listed as "obsolete" and most of them are not in current use. The claim is also supported by very low frequency of occurrences of these words through checking corpora like the Corpus of Contemporary American English (COCA) and the British National Corpus (BNC). and so on. The Immediate Cause Linking Rule also classifies non-agentive verbs such as cough, shiver, tremble as unergatives because they are also internally caused. Verbs of emission, though is classified as unaccusatives by Perlmutter [1], are maintained as basically unergative. The existence of -er nominals related to many verbs of emission such as beeper, buzzer, clicker and flasher is consistent to the claim. However, verbs of emission also behave like unaccustives if they are interpreted as verbs of directed motion.

The second linking rule is 'the Directed Change Linking Rule, which indicates that the argument of a verb that corresponds to the entity undergoing the directed change described by that verb is its direct internal argument' [7]. This rule captures both verbs of change of state such as break and open and verbs of inherently directed motion such as fall and come. It distinguishes verbs of agentive manner of motion like walk and swim from directed motion verbs like come and $g o$. The former is unergative while the latter is unaccusative. The well-formedness of -er nominals with the former and the ill-formedness of -er nominals with the latter indicate the justification of the classification.

The third rule is 'the Existence Linking Rule, which maps the argument of a verb whose existence is asserted or denied onto the direct internal argument' [7]. According to this rule, verbs of existence and appearance should be considered as unaccusatives. Evidence for these verbs' status is found in the compatibility of these verbs in the there-insertion construction and incompatibility of them in the $V$ one's way construction. Since the first three linking rules do not account for the behavior of all single-argument verbs, Levin and Rappaport Hovav put forward the fourth linking rule, the Default Linking Rule, which indicates that an argument of a verb that does not fall under the scope of any other linking rules is its direct internal argument [7]. Take the roll verbs as an example. Though the roll verbs and the run verbs all denote manners of motion, they follow different rules. The former is found in unaccusative pattern under the Default Linking Rule while the latter is found in unergative pattern by the Immediate Cause Linking Rule.

In order to account for the necessity of four linking rules, Levin and Rappaport Hovav also propose an order of priority, with the Directed Change and Existence Linking Rules take precedence over the Immediate Cause Linking Rule, which in turn precedes the Default Linking Rule. In addition, to offer an explanation for 'unaccusative mismatches', Levin and Rappaport Hovav assume that variation in syntactic behaviors of certain verb classes are attributable to different lexical-semantic representations, each of which is mapped onto syntactic representations in regular way [7]. To sum up, immediate change, directed change and existence are three important semantic properties to determine the mapping of the single argument of an intransitive verb onto external or internal argument. The external and internal argument, then, map onto the syntactic position of subject and direct object respectively, 
distinguishing a verb either as unergative or unaccusative.

\section{The Gradient Approach}

The gradient approach, on the contrary, claims that agentivity and telicity are two key factors whose interaction affects the syntax of split intransitivity. Sorace $[13,14,15]$ proposes that monadic intransitive verbs are organized in a Split Intransitivity Hierarchy (henceforth: SIH) with 'telic change' at the core of unaccusativity and 'agentive atelic non-motional activity' at the core of unergativity. Verbs that are stative and non-agentive are the peripheral or noncore ones.

There are all together seven subclasses of intransitive verbs on the SIH. Verbs of change of location lie at the core unaccusative end because they have the 'highest dynamicity and telicity' [13]. In auxiliary-selecting languages, this subclass, regardless of agentivity of the argument, consistently selects $B E$ within and across languages. In English, -er nominals are supposed not to be derived from this subclass. The ill-formedness of -er nominals like *arriver, "leaver and "departer ${ }^{2}$ are consistent with the claim. Next along the hierarchy is change of state verb class. Contrary to Levin and Rappaport Hovav's classification [7], the SIH excludes dyadic change of state verbs such as break, open and sink in the hierarchy for their weak unaccusativity. This subclass only includes verbs denoting 'indefinite change' such as verbs of directed motion (rise) and monadic verbs of change of state (decay). Sorace [13] also includes verbs of appearance (appear, disappear) and verbs of happening (happen, occur) in this subclass. The classification made by Sorace is different from the one made by Levin and Rappaport Hovav [7], who treat verbs of appearance and existence as one group. Since verbs of change of state encode telicity to varying degrees, this verb class is less consistent than inherently telic verbs of location, exhibiting more variation. -Er nominals are also claimed not to be derived from this subclass.

The next two classes along the hierarchy are the peripheral unaccusatives, mainly verbs of continuation of state (stay, survive) and verbs of existence of state (exist, seem). All the verbs are non-dynamic but stative to varying degrees. Verbs of continuation of state denote negation of change while verbs of existence incorporate no change component at all. The stative verbs somewhat exhibit more variation than verbs of change of location and state. - Er formations with survive and stand, to some extent, is allowed, which is consistent to the prediction of the hierarchy. The order of the first four verb classes on the $\mathrm{SIH}$ is arranged in a decreasing order of aspectual

2 Though the word departer is also listed as an entry in dictionaries, it is rarely used nowadays and cannot be found in daily English. specification (from inherently telic to stative), while the syntactic variation of these verb classes tends to be in an increasing order (from consistent to variation).

Verbs denoting agentive non-motional controlled process (work, play) lie at the core end of unergativity. These verbs are agentive but they still can take non-agentive subjects. This subclass exhibits the most consistent unergative behavior. In English, nonevent -er nominals can be derived from this subclass and usually refer to the agents of base verbs. Along the hierarchy of the unergative end, the next verb class is non-core verbs of controlled motional process (run, swim). Verbs in this group are sensitive to the features that telicize the predicate and the agentivity of the subjects as well. Verbs of uncontrolled process consist of verbs denoting involuntary bodily function (sweat, cough) and verbs of emission (creak, shine). The generalization is that the single argument of this subclass lacks volitionality and is most susceptible to syntactic variation. Non-core verbs of unergative end, as predicted, exhibit variation in forming -er nominals. - $E r$ nominals formed with verbs of emission such as buzzer and clicker are acceptable, which -er nominals formed with verbs like cough and tremble are somewhat unacceptable.

\section{Discussion and Conclusions}

Although both approaches tend to tackle with the lexical constraints on split intransitivity at the semantics-syntax interface, they differ in several aspects. First of all, linking rules proposed by Levin and Rappaport Hovav [7] are language-specific while the SIH is claimed to be language-universal. Second, the two approaches have different classifications of some verb classes. For example, Levin and Rappaport Hovav [7] take verbs of existence and verbs of appearance as one verb class that is sensitive to the semantic feature of Existence, while Sorace [13] classifies verbs of appearance and verbs of existence into two different subclasses with the latter exhibiting more variation than the former in their syntactic behaviors.

In addition, the two approaches differ in notions of agentivity and telicity. Levin and Rappaport Hovav [7] claim that the notion of 'internal causation' encompasses agentivity, since agentive verbs are often internally caused, but internally caused verbs are not necessarily agentive. Verbs of emission (shine, sparkle) present a good example for this claim. Telicity, in a similar way, is subsumed under a broader notion of 'directed change'. All telic verbs denote directed change, but directed change does not necessarily indicate telicity. They do not distinguish the inherently telic verbs of location (depart) from verbs implying indefinite change (rise). On the contrary, Sorace [13, 14] insists that inherent telicity, instead of directed change, is the determining factor in the consistent selection of $\mathrm{BE}$ in 
auxiliary-selecting langauges. The fundamental problem with Levin and Rappaport Hovav's model [7] is that they assume agentivity as well as telicity as discrete properties that a verb either has or does not have. Sorace [13, 14, 15], on the other hand, considers that these two features are actually gradient notions whose interpretation depends on the compositional factors.

To sum up, these two approaches classify split intransitivity into different subclasses based on the different semantic criteria they adopt. The gradient approach, compared with the projectionist approach, makes a step further to predict some verb classes are more consistent in their syntactic behaviors while others exhibit more variation. If the SIH holds true, the formation of -er nominals is supposed to be more compatible with core agentive unergatives than non-core unergatives. Since non-core verbs exhibit more variation, it is predictable that some -er nominals with unaccusatives are formed with non-core ones. The SIH, though receives much support from linguistic and experimental research, offers no explanation why certain semantic properties are more crucial to determine the verb's status as unaccusative or unergative. Further study should be conducted to find out the mechanism underlying the core-peripheral distinction, and to explore a more explanatory model of how gradience and consistence can co-exist.

\section{REFERENCES}

[1] Perlmutter, D. M. Impersonal passives and the unaccusative hypothesis. Proceedings of the 4th Annual Meeting of the Berkeley Linguistics Society, 1978: 157-189.

[2] Burzio, L. Italian syntax: a government-binding approach. Dordrecht u.a.: Reidel, 1986.

[3] Levin, Beth and Malka Rappaport Hovav. Nonevent -er nominals: A probe into argument structure. Linguistics, 1988: 1067-1083.

[4] Rappapot Hovav, Malka and Beth Levin. -Er nominals: Implications for the theory of argument structure. In Tim Stowell and Eric Wehrli (eds.), Syntax and semantics, 26. New York: Academic Press, 1992: 127-153.

[5] Alexiadou, A., \& Schäfer, F. On the syntax of episodic vs. dispositional-er nominals. In Artemis Alexiadou and Monika Rathert (eds.), The syntax of nominalizations across languages and frameworks. Berlin: Mouton de Gruyter, 2010: 9-38.

[6] Ono, Naoyuki. Agent Nominals, in Taro Kageyama and Hideki Kishimoto (eds.), Handbook of Japapnese Lexicon and Word Formation. Mouton de Gruyter, 2016: 559-630

[7] Levin, B., \& Rapport Hovav, M. Unaccusativity: at the syntax-lexical semantics interface. Cambridge, MA: MIT Press, 1995.

[8] Valin, R. D. V. Semantic parameters of split intransitivity. Language, 1990, 66(2), 221-260.
[9] Dowty D. Thematic Proto-Roles and Argument Selection. Language, 1991, 67(3):547-619.

[10] Levin, B. On the Nature of Ergativity. Doctoral dissertation, MIT, Cambridge, Mass, 1983.

[11] Ryder, Mary Ellen. Bankers and blue-chippers: an account of -er formations in Present day English. English Language and Linguistics, 1999, 3(2): 269-297.

[12] Schäfer, F. Naturally atomic -er nominalizations. Paper presented at the Workshop on Nominalizations (JeNom 3), Paris, 2010.

[13] Sorace, A. Gradients in auxiliary selection with intransitive verbs. Language, 2000, (76): 859-890.

[14] Sorace, A. Gradience at the lexicon-syntax interface: evidence from auxiliary selection. In A. Alexiadou, M. Everaert, \& E. Anagnostopoulou (eds.), The Unaccusativity Puzzle. Oxford: Oxford University Press, 2004: 243-268.

[15] Sorace, A. Gradience in split Intransitivity: the end of the unaccusative hypothesis. Archivio Glottologico Italiano, 2011, (96): 67-86. 